\title{
Processing of SAR Amplitude Images with Posting the Results on Web Server
}

\author{
Maria R. Ponomarenko*a and Ilya Yu. Pimanov ${ }^{\mathrm{b}}$ \\ ${ }^{a}$ St. Petersburg Mining University \\ 2, 21 Line, Saint Petersburg 199106, Russia \\ ${ }^{b}$ St. Petersburg Institute of Informatics and Automation RAS \\ 39, 14 Line, Saint Petersburg, 199178, Russia
}

Received 19.04.2016, received in revised form 28.07.2016, accepted 19.09.2016

The paper presents the processing and analysis of COSMO-SkyMED and Sentinel-1A amplitude images using texture analysis, image classification, composite images, and interpretation. It also describes the method of visualization the remote sensing data by placing it in analytical information system "RegionView».

Keywords: SAR amplitude image, Sentinel-1A, COSMO-SkyMED, web cartography.

\section{Обработка амплитудной составляющей}

\section{радарных снимков}

с размещением результатов на веб-сервере

\author{
М.Р. Пономаренко ${ }^{a}$, И.Ю. Пиманов ${ }^{\sigma}$ \\ ${ }^{a}$ Санкт-Петербургский горный университет \\ Россия, 199106, Санкт-Петербург, 21-я линия В.О., 2 \\ ${ }^{6}$ Санкт-Петербургский институт информатики \\ и автоматизаччи РАН \\ Россия, 199178, Санкт-Петербург, 14-я линия В.О., 39
}

В статье выполнены обработка и анализ амплитудной составляющей радарных снимков Cosmo-SkyMED u Sentinel-1A с использованием методов текстурного анализа, создания композитных изображений, неконтролируемой классификации, дешифрирования. Описан способ визуализачии результатов обработки данных дистанщионного зондирования Земли на примере их размещения в информационно-аналитической системе «Регион-В».

(c) Siberian Federal University. All rights reserved

* Corresponding author E-mail address: pnmry@yandex.ru 
Ключевые слова: радарные снимки, амплитудная информация, Sentinel-1A, Cosmo-SkyMED, веб-картография.

\section{Introduction}

Amplitude information of synthetic aperture radar (SAR) images is widely applied to study the Earth's surface. A lot of vegetation, soil, farmland, urban areas studies, also topographic and thematic mapping are based on amplitude data. Their processing techniques are being actively improved. The key processing methods are texture analysis, image classification, composite images, and interpretation.

The choice of the method largely depends on characteristics of the input image. In case of single polarization data, the most appropriate tool is texture analysis [1,2]. There are different approaches to texture description, for instance, the statistical approach uses grey-level co-occcurance matrix (GLCM) to calculate features that can be combined into RGB-composite for further interpretation $[3,4]$.

The speckle noise on radar images is used for calculation of texture feature as speckle divergence. The combination of speckle divergence and intensity can applied for identification of urban areas with high accuracy [5].

The different types of image classification can be used for textural images as well as original data. The most commonly used are algorithms of unsupervised classification - Isodata and K-means [2].

Various types of composite images are highly informative. For instance, on the basis of amplitude information of two multi-temporal images and their phase coherence we can create multi-temporal coherent composite (MTC). Depending on temporal baseline it can be applied for interpretation and monitoring of different objects. SAR and optical data fusion provides extra information about the objects and allows to identify their changes over time [6,7]. The change detection can also be performed using the above mentioned methods of texture analysis and classification.

The processing of full polarimetric SAR products includes various types of polarimetric decomposition with further classification of the resulted image [8]. The full polarimetric images are very useful in vegetation and farmland analysis. For example, they can be used to count such vegetation indices as RVI (Radar Vegetation Index) and LAI (Leaf Area Index) to evaluate crop and vegetation productivity [9-11].

The interpretation of SAR and optical images differs because of radar data characteristics such as speckle noise, foreshortening, layover and shadowing effect that greatly complicate data processing.

Despite all advantages of amplitude data, the main application of SAR images is still monitoring of surface and structures deformation based on long-term series of images but in fact only a phase component is processed. As a result a large amount of amplitude data remains unused. Moreover, today the world radar data archive is filling in with free Sentinel-1A images. The main attention is given to improvement of Sentinel data processing methods and searching for their new applications.

In this study COSMO-SkyMED and Sentinel-1A images are used to test such processing methods as texture analysis, image classification, composite images, and interpretation. The processing results are posted on web server using standard protocols.

$$
-995-
$$




\section{Methods}

The input data were COSMO-SkyMED and Sentinel-1A images of the central part of Kola Peninsula, Murmansk region (Table 1). The data processing was performed in Sentinel Toolbox, ERDAS Imagine, and QGIS.

The pre-processing included orthorectification and speckle filtering. The application of Refined Lee filter reduced the impact of speckle noise and improved visual perception and readability of images, highlighted borders and linear objects, which simplified the process of visual interpretation.

The GLCM was used to carry out the texture analysis of COSMO-SkyMED image, as a result the RGB-composite of entropy (red), contrast (green) and angular second moment (blue) was created. The outcomes can be interpreted either visually, as created image is more «readable», or by analyzing the relation between numerical values of textural characteristics and nature of the objects. The following RGB combination was used for dual polarimetric Sentinel-1A images: VH intensity for red, $\mathrm{VV}$ intensity for green and ratio $|\mathrm{VV} / \mathrm{VH}|$ for blue. Moreover we combined COSMO-SkyMED and Sentinel-1A images and got a new product containing three polarizations though with different spatial resolution.

For the resulted images we applied unsupervised classification using Isodata algorithm creating 7 classes for COSMO-SkyMED image and 13 classes for Sentinel-1A image. The classified images allowed to identify areal hydrography objects. Nevertheless, during detailed examination of the hydrography class we can notice some shadowing effects, which were not detected using DEM at

Table 1. Input data characteristics

\begin{tabular}{|c|c|c|}
\hline Data characteristics & COSMO-SkyMED & Sentinel-1A \\
\hline Date & 25.09 .2014 & 19.09 .2015 \\
\hline Pixel size & $3 \mathrm{~m}$ & $5 \times 20 \mathrm{~m}$ \\
\hline Mode & Stripmap (SM) & Interferometric Mode (IW) \\
\hline Polarization & HH & VH, VV \\
\hline
\end{tabular}

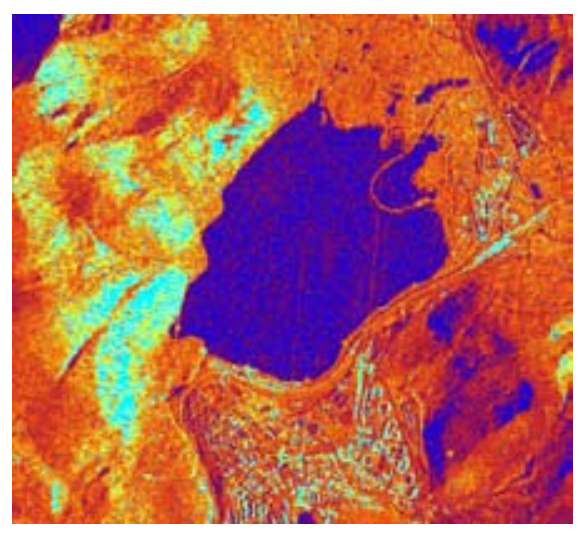

Fig. 1. Cosmo-SkyMED RGB-composite: entropy (red), contrast (green), ASM (blue)

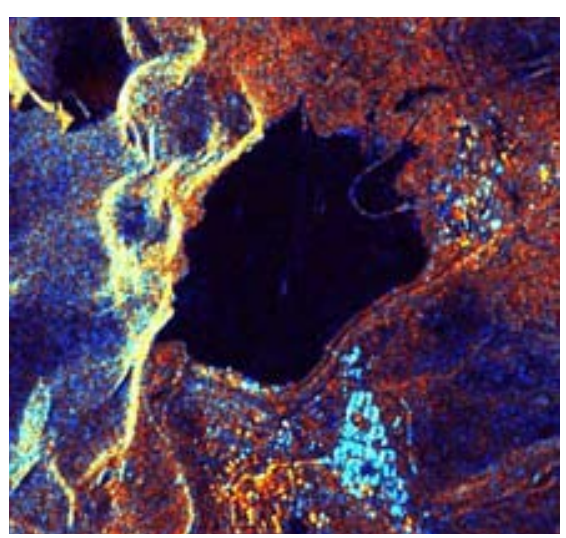

Fig. 2. Sentinel-1A RGB-composite: VH intensity (red), VV intensity (green), $|\mathrm{VV} / \mathrm{VH}|$ (blue) 
the stage of geometric correction. On the one hand, this complicates the process, forcing to apply additional operations for selecting hydrography. On the other hand, it allows to completely remove the shadow for further processing.

To identify more complex objects such as settlements and industrial areas we calculated speckle divergence, combined it with intensity and performed image classification using the Isodata algorithm. The analysis of processed data made it possible to obtain the boundaries of urban areas. The buildings and constructions were distinguished manually based on Cosmo-SkyMED data.

For the verification and correction of the results we used additional information: SPOT 5 and Landsat 8 OLI images, OpenStreetMap data etc. The more efficient processing was done with the pan-sharpening operation. The resolution of multi-spectral images was increased using radar images: COSMO-SkyMED image was co-processed with SPOT 5 data, S1A image - with L8 OLI data.

\section{Results}

The thematic processing allowed us to estimate the efficiency of the applied methods, analyze the information content (interpretation properties) of the radar images and compare CosmoSky-MED and Sentinel-1A data (Table 2).

The set of geoinformational layers obtained on the base of radar data can be used to create and update different types of maps [12]. It should be taken into account that their scale depends on the spatial resolution of the original data (Table 3).

Table 2. Results of the interpretation

\begin{tabular}{|l|l|l|}
\hline \multirow{2}{*}{ Object classes } & \multicolumn{2}{|c|}{ Characteristics } \\
\cline { 2 - 3 } & \multicolumn{1}{|c|}{ COSMO-SkyMED } & \multicolumn{1}{|c|}{ Sentinel-1A } \\
\hline Hydrography & $\begin{array}{l}\text { Water areas more than } 2000 \mathrm{~m}^{2} \text { and rivers } \\
\text { wider than } 10 \mathrm{~m} \text { are identified very clearly. } \\
\text { The interpretation of linear hydrography } \\
\text { may be complicated by objects on river } \\
\text { banks. }\end{array}$ & $\begin{array}{l}\text { Water areas more than } 8000 \mathrm{~m}^{2} \text { are well } \\
\text { recognized. In some cases it is possible to } \\
\text { identify rivers using indirect indications. }\end{array}$ \\
\hline Urban areas & $\begin{array}{l}\text { Buildings and constructions larger than } \\
\text { 2000 m² are confidently identified, but this } \\
\text { figure varies depending on the shapes of } \\
\text { objects. }\end{array}$ & $\begin{array}{l}\text { Settlement boundaries are identified, } \\
\text { buildings are not recognizable. }\end{array}$ \\
\hline Roads & $\begin{array}{l}\text { Railways are detected with high accuracy. } \\
\text { However the amount of tracks is } \\
\text { unrecognizable. } \\
\text { Highways are allocated precisely too } \\
\text { except for those that run though the } \\
\text { built up areas and are overshadowed by } \\
\text { buildings. } \\
\text { In general roads wider than 10 m are best } \\
\text { to recognize. }\end{array}$ & $\begin{array}{l}\text { We can recognize only some railways and } \\
\text { roads. } \\
\text { Roads within settlements are not } \\
\text { recognized. }\end{array}$ \\
\hline Relief & $\begin{array}{l}\text { General features of relief, thalwegs and watersheds are detected. On COSMO-SkyMED } \\
\text { images of quarry benches and slopes are well recognized. }\end{array}$ \\
\hline $\begin{array}{l}\text { Due to a poor vegetation the automatic identification failed. However having some a } \\
\text { priori knowledge it is possible to assume the vegetation based on differences in texture } \\
\text { and brightness. }\end{array}$ \\
\hline
\end{tabular}


Table 3. Usage of radar images according to their spatial resolution

\begin{tabular}{|c|c|c|}
\hline Usage of data & COSMO-SkyMED $(3 \mathrm{~m})$ & Sentinel-1A $(5 \times 20 \mathrm{~m})$ \\
\hline Map updating & $1: 10000$ & $1: 100000$ \\
\hline Map compilation & $1: 25000$ & $1: 200000$ \\
\hline
\end{tabular}

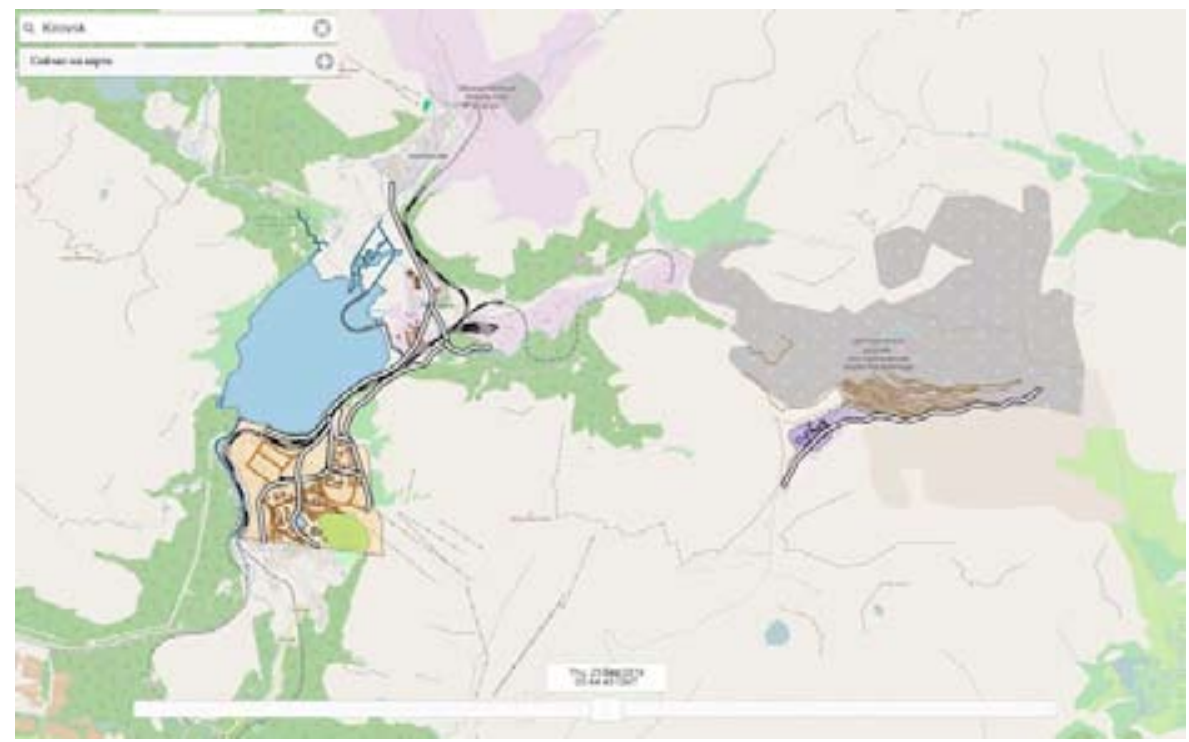

Fig. 3. Presentation of the results in RegionView

The best way to organize the storage of input data and processing results is using temporal data model (TDM). The key feature of applied TDM is bitemporality. This suggests fixing the time of data relevance and the transaction time (the time of data recording into the storage) which greatly facilitates the search of the results related in time [13, 14].

The analytical information platform «RegionView» created in SPIIRAS was used to release the results of the research. «RegionView» is a modular distributed system comprising server applications, GIS servers and database servers. All components are designed with the use of open-source software and do not require the purchase of paid licenses. The modular principle of construction and use of standard protocols of data exchange provide flexible placement of components of the system. «RegionView» is a tool with professional features that do not require professional knowledge in geoinformatics, computer and information technology. The system allows data viewing using WMS (Web Map Service) and WFS (Web Feature Service) standard protocols (without transmission and download), co-editing and access control.

\section{Conclusions}

The various methods of automatic interpretation of SAR images allow us to identify the most of terrain objects. However, the final allocation of their borders and contours is still carried out only by the operator. The visual recognition of objects is complicated due to the specifics 
of radar data. It requires the use of auxiliary materials and thorough pre-processing for image enhancement.

The application of the proposed method improves the accuracy of the interpretation. The accuracy of coastline identification, the total length of recognized railways and roads, and also the amount of identified buildings (for COSMO-SkyMED data) have increased. The analysis of the results confirmed the possibility of the compilation and updating of maps: from large scale (according to the COSMO-SkyMED data) to medium scale (according to Sentinel-1A data).

The results were posted on web server. The access to these data is carried out by WMS and WFS standard protocols. Described methods allow to store data saving their versioning in order to analyze and monitor terrain objects.

\section{Acknowledgments}

The research described in this paper is partially supported by the Russian Foundation for Basic Research (grants 15-08-08459, 16-08-00510, 16-07-00925) Program STC of Union State "MonitoringSG” (project 1.4.1-1), State researches 0073-2014-0009, 0073-2015-0007.

\section{References}

[1] Haralick R.M. Statistical and structural approaches to texture. Proceedings of the IEEE, 1979, 67(5), 786-804.

[2] Tou J.T., Gonzalez R.C. Pattern Recognition Principles. Reading, MA: Addison-Wesley, 1974, $378 \mathrm{p}$.

[3] Родионова H.B. Текстурная RGB-сегментация одноканальных TerraSAR-X изображений. Современные проблемы дистанционного зондирования Земли из космоса, 2014, 11(1), 301-307 [Rodionova N.V. One channel TerraSAR-X image textural RGB segmentation. Current Problems in Remote Sensing of the Earth from Space, 2014, 11(1), 301-307 (in Russian)].

[4] Родионова Н.В. Текстурная сегментация одноканальных изображений: примеры применения. Современные проблемы дистанционного зондирования Земли из космоса, 2012, 9(3), 65-69 [Rodionova N.V. One channel texture based segmentation: application examples. Current Problems in Remote Sensing of the Earth from Space, 2012, 9(3), 65-69 (in Russian)].

[5] Thiel M., Esch T., Schenk A. Object-oriented detection of urban areas from TerraSAR-X data. The International Archives of the Photogrammetry, Remote Sensing and Spatial Information Sciences, 2008, XXXVII-B8, 23-26.

[6] Пиетранера Л., Чезарано Л., Бритти Ф., Джентиле В., Кантемиров Ю.И. Новый продукт MTC, рассчитываемый по данным COSMO-SkyMed. Геоматика, 2012, 1(14), 46-51 [Pietranera L., Cesarano L., Britti F., Gentile V., Kantemirov Yu.I. New MTC product based on COSMO-SkyMed data. Geomatics, 2012, 1(14), 46-51 (in Russian)].

[7] Кантемиров Ю.И. Применение космических радарных съемок для задач тематического картографирования и мониторинга изменений. Вестник СибГАУ, 2013, 5(51), $54-57$ [Kantemirov Yu.I. Satellite SAR data usage for thematic mapping and change detection purposes. Vestnik SibGAU, 2013, 5 (51), 54-57 (in Russian)].

[8] Cloude S.R., Pottier, E. A review of target decomposition theorems in radar polarimetry. IEEE Transactions on Geoscience and Remote Sensing, 1996, 34(2), 498-518.

$$
-999-
$$


[9] Yamada Y. Preliminary study on the radar vegetation index (RVI) application to actual paddy fields by ALOS/PALSAR full-polarimetry SAR data. The International Archives of the Photogrammetry, Remote Sensing and Spatial Information Sciences, 2015, XL-7/W3, 129-131.

[10] McNairn H., Shang J., Jiao X., Deschamps B. Establishing crop productivity using RADARSAT-2. International Archives of the Photogrammetry, Remote Sensing and Spatial Information Sciences, 2012, XXXIX-B8, 283-287.

[11] Salberg A., Solberg S., Weydahl D.J., Astrup R.A. Leaf Area Index Estimation using ENVISAT ASAR and Radarsat-2. Norsk Regnesentral notat, 2009, SAMBA/30/09, 37 p.

[12] Пономаренко М.Р. Совершенствование методики обновления крупномасштабных карт с использованием данных ДЗЗ и ГИС-технологий. Региональные проблемы дистанционного зондирования Земли: материаль II Международной научной конференции, Красноярск: Сибирский федеральный университет, 2015, 197-199 [Ponomarenko M.R. Development of largescale mapping methods using remote sensing data and GIS-technologies. Regional Problems of Earth Remote Sensing: proceedings of the II International Scientific Conference, Krasnoyarsk: Siberian Federal University, 2015, 197-199 (in Russian)].

[13] Зеленцов В. А., Крыленко И. Н., Пиманов И. Ю., Потрясаев С. А., Соколов Б. В., Ахтман Й. Основы построения системы обработки данных дистанционного зондирования Земли на базе сервис-ориентированной архитектуры. Известия высших учебных заведений. Приборостроение, 2015, 58(3), 241-243 [Zelentsov V.A., Krylenko I.N., Pimanov I.Y., Potryasaev S.A., Sokolov B.V., Akhtman Yo. Principles of Earth remote sensing data processing system design on the base of service oriented architecture. Izvestiya Vysshikh Uchebnykh Zavedeniy. Priborostroenie, 2015, 3(58), 241-243 (in Russian)].

[14] Sokolov B.V., Pashchenko A.E., Potryasaev S.A., Ziuban A.V., Zelentsov V.A. Operational Flood Forecasting As a Web-Service. Proceedings of the 29th European Conference on Modelling and Simulation (ECMS-2015), Albena (Varna), Bulgaria, 2015, 364-370. 